\title{
International E-Discovery: Navigating the Maze
}

\author{
By Erica M. Davila*
}

\section{$\underline{\text { Table of Contents }}$}

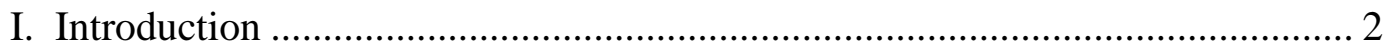

II. Globalization and the Growth of Electronic Data .............................................. 3

III. International Data Protection Laws ......................................................... 6

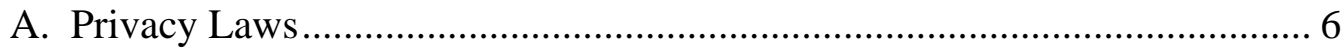

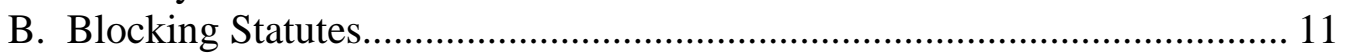

C. Secrecy Laws............................................................................................. 14

IV. Existing United States Law on International Discovery.................................. 16

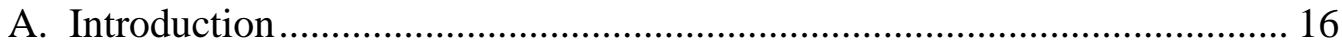

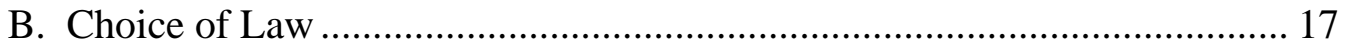

1. FRCP or the Hague Convention ............................................................ 17

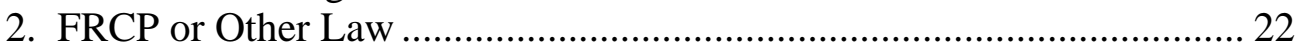

C. Orders for Production.............................................................................. 24

1. Subpoena Power and Personal Jurisdiction .............................................. 24

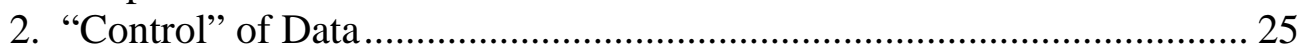

3. Conflicts with Foreign Law and the Balancing Test ............................... 27

V. Additional Considerations for International Discovery of ESI........................ 31

A. Balancing for International ESI ............................................................... 31

1 Hardship of Compliance ........................................................................ 32

2 Good Faith of Party Opposing the Discovery …………............................ 35

3 Requests to Parties and Non-Parties .......................................................... 36

4 Whether ESI Originated in the United States ........................................... 38

B. Recourse for Non-Production.................................................................... 39

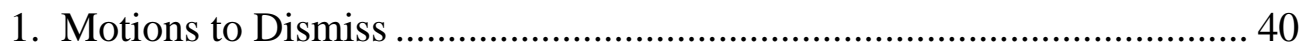

2. Adverse Inference Instructions ................................................................ 40

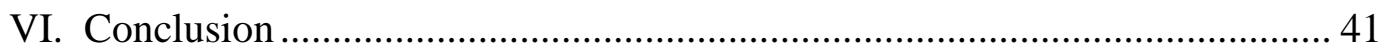

* Rutgers School of Law, J.D. Candidate 2008; Cornell University, A.B. Biological Sciences, Neurobiology and Behavior Concentration 2000 


\section{Introduction}

Globalization and the growing mountain of electronically stored information (“ESI”) will inevitably lead to an increase in discovery requests for ESI located abroad. But no consistent methodology exists for United States courts to evaluate whether discovery of ESI abroad is appropriate, and if so, what the consequences are for failure to comply with a discovery order. As international commerce depends on "the ability of merchants to predict the likely consequences of their conduct in overseas markets," ${ }^{1}$ United States courts need to apply a consistent standard to decisions involving the discovery of international ESI. This paper reviews existing law related to international discovery and electronic discovery (“e-discovery”) and proposes a blended approach to be considered by courts to evaluate discovery of international ESI.

This blended approach balances conflicting policy concerns related to discovery of international ESI including: (1) the equitable consideration of ensuring that multi-national organizations doing business in the United States are not given an unfair advantage in United States courts by avoiding burdensome discovery; and (2) comity considerations recognizing the inherent burden on foreign litigants of producing documents for discovery that may be protected by international law, compounded by the burden and cost characteristic of any ediscovery.

Section II of this article outlines how globalization has resulted in an increase in discoverable ESI abroad. Section III briefly reviews the international

\footnotetext{
${ }^{1}$ Gau Shan Co. v. Bankers Trust Co., 956 F.2d 1349, 1355 (6th Cir. 1992).
} 
data protection laws that protect this ESI from discovery in the United States. Section IV provides an overview of the existing law governing international discovery. Finally, Section V proposes additional factors to be considered by courts to determine whether discovery of international ESI is warranted, and also discusses avenues of recourse for non-production.

\section{Globalization and the Growth of Electronic Data}

Merriam-Webster's Online Dictionary defines globalization as "the development of an increasingly integrated global economy marked especially by free trade, free flow of capital, and the tapping of cheaper foreign labor markets.”2 ${ }^{2}$ This definition dates back to $1951 .^{3}$ In 1962, Marshall McLuhan proposed his "global village" thesis, predicting that the ability to instantaneously communicate would soon create a global village. ${ }^{4}$ Geographer David Harvey later argued that this global village phenomenon is characterized by a "time-space compression" that arises from inexpensive air travel and the use of telephones, fax, and e-mail. ${ }^{5}$

McLuhan's predictions were correct: the ability to instantaneously communicate with someone halfway across the world has created a global marketplace. The ability to access information instantaneously, regardless of

\footnotetext{
${ }^{2}$ http://www.merriam-webster.com (select dictionary option then type "globalization”).

${ }^{3} I d$.

${ }^{4}$ Marshall Mcluhan, The Gutenberg Galaxy: The Making of Typographic Man (Univ. of Toronto Press 1962).

${ }^{5}$ David Harvey, The Condition of Postmodernity: An Enquiry into the ORIGins of CUltural CHANGE 232 (Blackwell 1992).
} 
where the data is physically located, has created opportunities for companies to host operations and systems in multiple countries and centralize data systems for global operations.

Companies are meeting the challenge of globalization by creating networks of electronic data that allow for employees around the world to connect to the same set of data wherever it is located. In fact, "[c]reating one global IT department and architecture is a focus for many companies." ${ }^{\prime 6}$ For instance, in 2004 the Bank of New York implemented a centralized customer-data environment that gave 1,650 employees worldwide a view of customer data. ${ }^{7}$ Likewise, Johnson Controls Inc. (“Johnson”), a manufacturer of automotive parts with 118,000 employees worldwide and factories on five continents, shares applications globally. ${ }^{8}$ Johnson hosts human resources, benefits, and payroll data in the United States, but stores its financial information in Germany; however, all worldwide locations can access this data. ${ }^{9}$

In addition to creating global information technology infrastructures, companies are outsourcing business processes to vendors overseas. Corporations "are no longer focusing on the physical location where processing may be occurring but are using a 'best shore' strategy where they put their resources in

\footnotetext{
${ }^{6}$ David M. Ewalt et al., Global Forces, Information WeeK, May 31, 2004, at 40.

${ }^{7} I d$.

${ }^{8} I d$.

${ }^{9}$ Id.
} 
the right location, whether that's the Far East, U.S., Canada, or wherever."10 For instance, Procter \& Gamble has an accounts payable operation set up in Bangalore, India that processes invoices from French perfume makers, which are paid from bank accounts in the United Kingdom. ${ }^{11}$ According to Gartner Group, the size of the business process outsourcing market was $\$ 173$ billion in 2007. Of that sum, \$24 billion was outsourced to offshore contractors. The most commonly outsourced processes "include auditing, payroll, human resources, benefits management, contact centers, payment/claims processing, real estate management and supply chain management.”12 Because the data protection laws of the countries in which the data is created, processed, and hosted may protect this data, these global infrastructures pose difficulties when it comes time for discovery in United States litigation.

Although international discovery is not a new problem, the growth of international data infrastructures, global companies, and the explosion of ESI will bring the issues of e-discovery to the forefront of international litigation. Courts will be faced with comity considerations and issues related to the burden and cost of e-discovery, ${ }^{13}$ as well as complex international data protection laws.

\footnotetext{
${ }^{10} I d$. (quoting Larry Lozon, VP of hosting services for EDS, one of the world's largest providers of outsourced business-technology services).

${ }^{11}$ Stan Gibson, The Year of Living Globally, EWeek.com, November 22, 2006, http://www.eweek.com/article2/0,1895,2063024,00.asp.

12 John Bugh, Outsourcing Risks and Rewards, Customer Interaction Solutions, July 1 2006, at 40(3), available at http://www.tmcnet.com/call-center/0706/outsourcing-risks-and-rewards.htm.

${ }^{13}$ But why is discovery of ESI different than traditional discovery of paper? The answer among other things is volume. Kenneth J. Withers, Electronically Stored Information: The December 2006 Amendments to the Federal Rules of Civil Procedure, 4 Nw. J. OF TECH. \& INTELL. PROP. 171, 173 (2006). In addition to volume, Withers notes that ESI differs from paper because of the virtual inability to delete ESI, the additional data that must be associated with ESI in order to fully
} 


\section{International Data Protection Laws}

The increase in globalization and ESI has led to legislation in foreign countries to protect the disclosure of certain information. Some of this legislation has specifically targeted the protection against production of data for litigation. ${ }^{14}$ A party seeking protection against compelled discovery, relying on the basis that foreign law bars the production, has the burden of proving that the foreign law actually prohibits production of the data at issue. ${ }^{15}$ The following summarizes the most common categories of data protection laws.

\section{A. Privacy Laws}

United States privacy laws have developed as a result of court actions and are not codified at the federal level. The United States Constitution does not delineate privacy as a fundamental right. However, privacy has been recognized as a guaranteed right from the penumbra of a number of constitutional provisions. ${ }^{16}$

The view on privacy varies internationally and is strictly regulated in many countries. For instance, the European Union Data Protection Directive

\footnotetext{
describe it, and the difficulty of reading legacy data. Id. Approximately 800 megabytes of ESI is produced per person per year across the world. Peter Lyman and Hal R. Varian, How Much Information? (October 27, 2003), http://www2.sims.berkeley.edu/research/projects/how-muchinfo-2003 (last visited Jan. 11, 2008). It would take the equivalent of 30 feet of paper to store 800 megabytes of ESI. Id. The volume is partially attributable to the way in which we communicate. Prior to electronic communication, communications were not usually recorded. Withers, at 174. Volume is also attributable to the replication of ESI in various locations. Id. For example, multiple copies of the same e-mail message are often retained - one copy for the sender and one copy for each of the recipients.

${ }^{14}$ See, e.g., Business Records Protection Act, R.S.O. 1990 c. 54 (Can.).

${ }^{15}$ In re Sealed Case, 825 F.2d 494, 498 (D.C. Cir. 1987).

${ }^{16}$ See, e.g., Griswold v. Connecticut, 381 U.S. 479, 483-84 (1965).
} 
(“Data Protection Directive”) establishes a regulatory framework around the movement and treatment of personal data in the European Union (“EU”). ${ }^{17}$ In addition to the personal data protection laws, the European Court of Human Rights ("ECHR") has found that the right to private communications in the workplace is a fundamental freedom covered under the Convention for the Protection of Human Rights and Fundamental Freedoms ("Human Rights Convention $^{18 \text { »). }}{ }^{19}$ Laws promulgated in compliance with the Data Protection Directive and the views in the EU on workplace privacy provide barriers to complying with discovery in the United States.

The Data Protection Directive allows the transfer of personal data between countries only if the country receiving the data ensures an adequate level of protection. $^{20}$ In response to the restrictive Data Protection Directive, the United States Commerce Department negotiated a "safe harbor" with the EU, which provides requirements that United States companies may choose to adhere to in order to participate in the free exchange of personal data with companies in the EU. ${ }^{21}$ Article 26 of the Data Protection Directive also allows for the transfer of

\footnotetext{
${ }^{17}$ Council Directive 95/46/EC of the European Parliament and Council of 24 Oct. 1995 on the Protection of Individuals with Regard to the Processing of Personal Data and on the Free Movement of Such Data, 1995 O.J. (L281) (Nov. 23, 1995) at Art. 7 [hereinafter Data Protection Directive].

${ }^{18}$ European Convention for the Protection of Human Rights and Fundamental Rights, as amended by Protocol No. 11, Rome, 4.XI.1950, art. 8 [hereinafter Human Rights Convention].

${ }^{19}$ Copland v. U.K., 62617/00 [2007] ECHR 253, 42 (3 April 2007).

${ }^{20}$ Data Protection Directive, supra note 17, at Art. 25. But see Id. at Art. 13(d) (authorizing members to adopt measures to allow for the transfer of data for the prosecution of criminal offenses).

${ }^{21}$ As part of the safe harbor provision, companies wishing to obtain information under the safe harbor provision must publicly disclose their privacy policies and "be subject to the jurisdiction of
} 
data between companies using "standard contractual clauses." ${ }^{22}$ Personal data has been broadly construed under the Data Protection Directive to include e-mail and other commonly requested ESI. ${ }^{23}$

United States courts have found that privacy laws promulgated under the Data Protection Directive reflect a legitimate foreign interest that needs to be considered when deciding discovery issues. In In re Vitamins Antitrust Litigation, German defendants claimed that the German Data Protection Act, created to comply with the Data Protection Directive, prohibited disclosure of the employee data requested by plaintiffs. ${ }^{24}$ A violation of the German Data Protection Act is a criminal offense in Germany that could result in substantial fines or prison terms. $^{25}$ The District Court in the District of Columbia held that even if the German Data Protection Act prohibited disclosure of the requested data, disclosure could be compelled if plaintiffs showed: “(1) that the information at issue is 'necessary' to protect public interests and/or the interests of the plaintiff;

\footnotetext{
the Federal Trade Commission (FTC) under Section 5 of the Federal Trade Commission Act which prohibits unfair or deceptive acts or practices in or affecting commerce, or that of another statutory body that will effectively ensure compliance with the Principles”. Commission Decision (EC) No. 2000/520 of 26 July 2000, at 5, 2000 O.J. (L 215), 7, pursuant to Data Protection Directive, supra note 17.

${ }^{22}$ Data Protection Directive, supra note 17.

${ }^{23}$ Article 29 Data Protection Working Party, Opinion 8/2001 on the Processing of Personal Data in the Employment Context, at 24, 5062/01/EN/Final WP 48 (Sept. 13, 2001) (concluding that "[t]here should no longer be any doubt that data protection requirements apply to the monitoring and surveillance of workers whether in terms of email use, internet access, video cameras or location data”).

${ }^{24} 2001$ U.S. Dist. LEXIS 8904, at *44-45 (D.D.C. June 20, 2001).

${ }^{25} I d$. at *46-47.
} 
and (2) the data subjects have no 'legitimate interest' in preventing disclosure of the information., ${ }^{26}$

The court ultimately found that the information was relevant to the plaintiffs' claims, but found that defendants had a legitimate interest in preventing disclosure. ${ }^{27}$ The defendants' interest in preventing disclosure was based on the fact that "individuals have a presumptively legitimate interest under German law in the nondisclosure of their personal information to residents of countries with non-equivalent personal data protection standards," and also on the fact that defendants might be subject to criminal liability in their own country. ${ }^{28}$ Even still, the court required a "privacy log" akin to a privilege log that would detail the information they believed was protected by the German Data Protection Act. ${ }^{29}$ Finally, the court noted that it was not barring discovery, and that if defendants placed items on the privacy log, discovery could still be litigated later. ${ }^{30}$

The same German Data Protection Act was also litigated in Salerno v. Lecia, Inc., where the District Court in the Western District of New York refused to compel discovery, finding the request overbroad and the discovery at issue irrelevant. $^{31}$

\footnotetext{
${ }^{26} I d$. at $* 49-50$.

${ }^{27}$ Id. at *72-73.

${ }^{28} I d$. at $* 52-53$.

${ }^{29} I d$. at $* 53-54$.

${ }^{30} I d$. at $* 56$.

${ }^{31} 1999$ U.S. Dist. LEXIS 7169, at*10-11 (W.D.N.Y. Mar. 23, 1999).
} 
In addition to privacy laws created under the Data Protection Directive, many countries view privacy in the workplace differently than the United States does. There is generally no expectation of privacy in workplaces in the United States, and so requesting and receiving e-mail in discovery is commonplace. In the EU, however, there is an expectation of privacy in the workplace, and so email sent and received via work accounts may not be discoverable.

In a recent holding by the ECHR, the court found that under the Human Rights Convention, which provides that "[e]veryone has the right to respect for his private and family life, his home and his correspondence," ${ }^{32}$ telephone calls and e-mails made by an employee from work fall within the Human Rights Convention's notion of "private life" because they may contain "personal information.”33 In that case, the court found that the employer's monitoring of telephone calls and e-mails without notice violated the employee's human rights under the Human Rights Convention. ${ }^{34}$

The ECHR is not alone in this line of thinking. The ECHR case was predated by two cases heard by the French Court of Cassation that interpreted both the Human Rights Convention and the Data Protection Directive. The court held in both instances that under almost no circumstances may an employer

\footnotetext{
${ }^{32}$ Human Rights Convention, supra note 18.

${ }^{33}$ Copland, supra note 19, at $₫ 42$.

${ }^{34}$ Id.
} 
inspect an employee's e-mail, files, or computer, even when the employer has reason to suspect wrongdoing. ${ }^{35}$

These holdings, combined with the Data Protection Directive's finding that personal data includes e-mail, ${ }^{36}$ raise some serious concerns about whether international law will prohibit discovery of foreign e-mail in United States litigation in the future. Surprisingly, there have been few examples of reported litigation involving requests for data covered by privacy laws created under the Data Protection Directive or data considered private under the Human Rights Convention. It is only a mater of time before this data becomes the object of United States litigation.

\section{B. Blocking Statutes}

Historically, foreign blocking statutes have been one of the most common impediments to United States discovery of information located abroad. The scope of the statutes varies, but they generally prohibit production of documents and disclosure of information related to a particular topic or industry. ${ }^{37}$ However, some like the French "blocking statute" seem to prohibit any discovery. The French statute provides in pertinent part:

\footnotetext{
${ }^{35}$ Philippe K. v. Cathnet-Science, Cour de Cassation, Chambre Sociale, Arret No. 1089 FS$\mathrm{P}+\mathrm{B}+\mathrm{R}+1$, Pourvoi No. J-03-40.017, 5/17/05 (holding that presence of erotic photos on employees desk was not grounds for searching his computer); Societe Nikon France v. M. Onof, Cass. soc., Oct. 2, 2001, Bull Civ. V, No. 291 (finding an employee's rights violated when the employer searched his computer upon suspicion employee was conducting a side business).

${ }^{36}$ See supra note 23 and accompanying text.

${ }^{37}$ See infra note 42.
} 
Subject to treaties or international agreements and applicable laws and regulations, it is prohibited for any party to request seek or disclose, in writing, orally or otherwise, economic, commercial, industrial, financial or technical documents or information leading to the constitution of evidence with a view to foreign judicial or administrative proceedings or in connection therewith. ${ }^{38}$

Many blocking statutes were enacted specifically to thwart United States discovery.

The first of these was Ontario, Canada's Business Records Protection Act. ${ }^{39}$ The statute was enacted after the District Court for the Southern District of New York ordered the Canadian subsidiaries of a New York corporation to produce documents located in Canada as part of a grand jury antitrust investigation. $^{40}$ Similarly, in 1956, the Netherlands enacted legislation prohibiting compliance with any decision of any other country regarding regulation of competition. ${ }^{41}$

A number of countries enacted blocking statutes in response to the United States Federal Maritime Commission's investigation of anticompetitive practices of international shipping conferences in the 1960s. ${ }^{42}$ In the 1970 s, more blocking

\footnotetext{
${ }^{38}$ French Penal Code Law No. 80-538, cited in Madden v. Wyeth, 2006 U.S. Dist. LEXIS 880, at *2 (N.D.Tex. Jan. 12, 2006).

${ }^{39} 1947$ Ont.Rev.Stat. c. 54.

${ }^{40}$ In re Grand Jury Subpoenas Duces Tecum Addressed to Can. Int'l Paper Co., 72 F. Supp. 1013 (S.D.N.Y. 1947).

${ }^{41}$ Economic Competition Act of June 28, 1956, amended by Act of Nov. 14, 1958, Art. 39.

${ }^{42}$ Restatement (THIRD) OF THE Foreign RELATIONS LAW § 442, cmt. background 4 (citing to the following statutes: Great Britain: The Shipping and Commercial Documents Act, 1964, c. 87; Federal Republic of Germany: Federal Maritime Shipping Act of May 24, 1965, Art. 11, [1965] Bundesgesetzblatt pt. II 833, 835; France: Law No. 68-678 of July 26, 1968 Relating to the Transmission of Documents and Information to Foreign Authorities in the Area of Maritime Trade, [1968] Jour.Off. 7267, [1968] B.L.D. 438; Norway: Act of June 16, 1967, Power for the King to Forbid Shipowners to Give Information, etc., to Foreign Authorities, Norges Lover 1685-
} 
statutes were enacted when the United States Department of Justice and others sought information concerning the participation of United States based companies in a worldwide Uranium cartel. ${ }^{43}$

Courts recognize that blocking statutes, like the French Blocking Statute, have been constructed purposefully to "provide [foreign nationals] with tactical weapons and bargaining chips in [United States courts]." ${ }^{44}$ Statutes that have been enacted "for the express purpose of frustrating the jurisdiction of the United States

1985 at 1726 (1986). Belgium: Law of March 27, 1969, concerning the Regulation of Marine Transport, [1969] Bull. Usuel des Lois et Arrêtés No. 723 at 500, amended to include Air Transport June 21, 1977, [1976] Id. No. 1490 at 1075; supplemented by Royal Decree of Feb. 6, 1979, [1979] Id. No. 464 at 319; Sweden: Ordinance Regarding Prohibition in Certain Cases for Shipowners to Produce Documents Concerning the Swedish Shipping Industry. [1966] Svensk Forfattningssamling No. 156, at 411).

${ }^{43}$ Restatement (THIRD) OF THE Foreign RELATIONS LAW $\S 442$, cmt. background 4 (citing to the following statutes: Australia: Foreign Proceedings (Prohibition of Certain Evidence) Act, 1976, Austl. Acts No. 121, amended by Foreign Proceedings (Prohibition of Certain Evidence) Amendment Act, 1976, Austl. Acts No. 202, replaced by Foreign Proceedings (Excess of Jurisdiction) Act, 1984, Austl. Acts No. 3; Canada: Uranium Information Security Regulations, Prov.Can.Stat. 1976-2368, Stat.O. \& R. 76-644 (Sept. 21, 1976), replaced by Prov.Can.Stat. 19772923, Stat.O. \& R. 77-836 (Oct. 13, 1977), in implementation of the Atomic Control Act, 1970, s. 9, Can.Rev.Stat. c. A-19, Foreign Extraterritorial Measures Act, Stat. Can.1984, c. 49; France: Law No. 80-538 of July 16, 1980 Relating to the Communication of Economic, Commercial, Industrial, Financial or Technical Documents or Information to Foreign Natural or Legal Persons, [1980] Jour.Off. 1799, English version with commentary, 75 Am.J.Int'l L. 382 (1981); Great Britain, Protection of Trading Interests Act, 1980 c. 11 s. 1-4; South Africa, Second General Law Amendment Act 94, 1974, § 2, 12 Stat. S. Africa 602).

${ }^{44}$ Compagnie Francaise D'assurance Pour Le Commerce, 105 F.R.D. 16, 30 (S.D.N.Y. 1984) (citations and quotes omitted); see also Valois of America v. Risdon Corp., 183 F.R.D. 344 (D.Conn. 1997) (declining to apply French Blocking Statute); Bodner v. Paribas, 202 F.R.D. 370, 375 (E.D.N.Y. 2000) (holding that the French Blocking Statute did not represent a significant interest of France because it was enacted specifically to give French litigants an advantage in foreign courts); Adidas (Can.) Ltd. v. SS Seatrain Bennington, 1984 U.S. Dist. LEXIS 16300, at *9-10 (S.D.N.Y. May 30, 1984) (declining to heed the French Blocking Statute in light of its purpose). 
courts”45 are not afforded the same weight by courts as foreign statutes that protect "significant interests” of foreign countries. ${ }^{46}$

\section{Secrecy Laws}

Secrecy laws have generally afforded the most protection to foreign litigants in United States courts. Although rarely providing absolute immunity from discovery, courts have viewed many secrecy laws as reflecting a "significant interest” of the foreign country in question. Because of this recognized significant interest and the associated need to perform a comity analysis before deciding on discovery, cases involving secrecy laws have produced the richest body of law around international discovery. Secrecy laws most commonly protect the disclosure of bank customer and corporate data.

One of the most frequently litigated bank secrecy laws is Article 47 of the Swiss Bank Law, which prohibits disclosure of bank customer information. Although the United States Supreme Court in Societe Internationale v. Rogers (“Societe Internationale”) ultimately found that United States interests under the Trading with the Enemy Act were significantly greater than Switzerland's interest

\footnotetext{
${ }^{45}$ In re Uranium Antitrust Litig., 480 F. Supp. 1138, 1143 (N.D. Ill. 1979).

${ }^{46}$ See Minpeco, S.A. v. Conticommidity Servs., Inc., 116 F.R.D. 517, 527-28 (S.D.N.Y. 1987) (holding that the Swiss Bank Secrecy Law protected the substantial interest in the protection of bank client account in formation); see also, RESTATEMENT (THIRD) OF THE FOREIGN RELATIONS LAW § 442 (1987) ("adjudication should take place on the basis of the best information available [and] ... statutes that frustrate this goal need not be given the same deference by courts of the United States as differences in substantive rules of law").
} 
in keeping bank customers' data secret, ${ }^{47}$ other courts have found that Switzerland's interest in the secrecy of bank information prohibits discovery. ${ }^{48}$

Some bank secrecy laws are not codified by statute but are construed to be “waivable privileges” held by bank customers. The German bank secrecy privilege is considered a waivable privilege and has been seen by United States courts as a weaker foreign interest that often does not trump the United States interests in discovery. For example, in United States v. First National City Bank, the Second Circuit found that Germany’s interests in bank secrecy were limited because the country chose to "leave the matter of enforcement to the vagaries of private litigation." 49

There are also "corporate" secrecy laws that prevent the disclosure of company information, often including information on assets, inventory, bank accounts, and corporate structure. For instance, in Richmark Corp. v. Timber Falling Consultants, the Ninth Circuit considered whether the People's Republic of China’s state secrecy laws prohibiting disclosure of information that "concerns the national economy and social development" barred discovery. ${ }^{50}$ The Ninth Circuit found that the statute did not bar the court from ordering discovery of a

\footnotetext{
47357 U.S. 197, 205-06 (1958).

${ }^{48}$ Minpeco, 116 F.R.D. at 527-28 (finding that Switzerland's interests in protecting bank customer information was paramount where discovery was sought from a non-party and was not expected to result in information significant to the litigation).

49 396 F.2d 897, 903 (2d Cir. 1968).

${ }^{50}$ Richmark Corp. v. Timber Falling Consultants, 959 F.2d 1468, 1478-79 (9th Cir. 1992) (citing to Collection of the Laws of the People's Republic of China 1363 Art. 8 (1989)).
} 
Chinese company's financial information and held the Chinese company in contempt for not complying with the order. ${ }^{51}$

In at least one case, a United States court found that a corporate secrecy statute held less weight when dealing with foreign subsidiaries of United States domiciled parent companies. In United States v. Vetco Inc., the Ninth Circuit found that the Swiss interest in prohibiting disclosure of business secrets, as reflected in Article 273 of the Swiss Penal Code, was diminished where the Swiss company was a subsidiary of a United States parent. ${ }^{52}$

\section{Existing United States Law on International Discovery}

\section{A. Introduction}

Discovery in the United States is built on the well-founded premise that all information that "appears reasonably calculated to lead to the discovery of admissible evidence" is discoverable. ${ }^{53}$ United States courts may order production of documents or other information "even if the information or the person in possession of the information is outside the United States." ${ }^{54}$ Foreign companies who do business in the United States are subject to the benefits and burdens of United States law, including the laws on discovery. ${ }^{55}$ In many cases,

\footnotetext{
${ }^{51} I d$.

52691 F.2d 1281, 1289 (9th Cir. 1981) (even the Swiss Attorney General conceded that the case “apparently does not concern a totally Swiss interest in confidentiality”).

${ }^{53}$ FED. R. CIV. P. 26(b)(1).

${ }^{54}$ Restatement (THIRD) OF Foreign RELATIONS LAW §442(1)(a).

${ }^{55}$ Id. at $§ 442(1)(\mathrm{a})$, Reporters Notes 1.
} 
United States corporations with foreign operations must also produce documents and ESI located abroad. ${ }^{56}$ When data is sought abroad, a court must first determine whether discovery will proceed under the Federal Rules of Civil Procedure (“FRCP”) or other law.

\section{B. Choice of Law}

\section{FRCP or the Hague Convention}

Two sets of procedural rules govern discovery of international data in the United States courts. ${ }^{57}$ These include the FRCP and the Hague Convention on Taking of Evidence Abroad in Civil or Commercial Matters (the "Hague Convention ${ }^{58 »)}{ }^{59}$ When data is sought from a party in country that is a signatory to the Hague Convention (a "State Party"), the court must determine whether to conduct discovery under the FRCP or the Hague Convention.

The FRCP, established in 1938, are promulgated by the United States Supreme Court and approved by the United States Congress. The FRCP have

\footnotetext{
${ }^{56}$ See, e.g., In re Investigation of World Arrangements, etc., 13 F.R.D. 280, 285 (D.D.C. 1952) (noting that if the "parent corporation has control over the affairs of the subsidiary and manages the subsidiary primarily for the interest of the parent, the courts will look through the corporate entity"). Note that other countries - for example, Great Britain- have the opposite rule where parent companies are not generally responsible for production of documents at foreign subsidiaries. See, e.g., Lonrho Ltd. v. Shell Petroleum Co., [1980] 1 W.L.R. 627 (H.L.).

57 "International data" is defined here as data in the custody or control of a foreign company.

${ }^{58}$ Mar. 18, 1970, 23 U.S.T. 2555, T.I.A.S. No. 7444 (codified at 28 U.S.C. § 1781) [hereinafter Hague Convention].

${ }^{59}$ See Societe Nationale Industrielle Aerospatiale et al. v. U.S. Dist. Ct. for the S. Dist. of Iowa (Aerospatiale), 482 U.S. 522, 533 (1987) (stating that "both the discovery rules set forth in the Federal Rules of Civil Procedure and the Hague Convention are the law of the United States.”).
} 
been amended eleven times in their history, with significant revisions to address e-discovery taking effect on December $1,2006 .^{60}$

The Hague Convention is a multilateral treaty that was opened for signature on March 18, $1970 .^{61}$ As of December 7, 2007, there were forty-four State Parties that had signed the treaty. ${ }^{62}$ The United States signed on August 27, 1970. The Hague Convention was designed to help reconcile differences between civil and common law discovery procedures of the State Parties. Prior to the Hague Convention's taking effect, countries were forced to use cumbersome and time-consuming consular or diplomatic channels in order to obtain evidence in other countries. The Hague Convention applies only between State Parties and provides for compulsion of evidence by letters of request, and for the taking of depositions before consuls and court-appointed commissioners. ${ }^{63}$ Article 9 provides that letters of request will be executed in accordance with the law of the State Party that is responding to the request.

\footnotetext{
${ }^{60}$ The Federal Rules of Civil Procedure were amended again effective December 1, 2007. However, these changes were mostly stylistic and did not substantively affect rules related to discovery.

${ }^{61}$ The Hague Convention was concluded on March 18, 1970 and entered into force on October 7, 1972.

${ }^{62}$ Hague Conference on Private Int'l Law, Status table, http://www.hcch.net/index_en.php?act=conventions.status\&cid=82 (last visited Dec. 1, 2007). For a full updated status of the Convention, see the Hague Conference's website at www.hcch.net.

${ }^{63}$ Article 17 provides that court appointed commissioners may take depositions. Article 33 provides that any State may exclude, in whole or in part, the provisions of Chapter II relating to diplomatic and consular agents and commissioners, including Article 17 provisions. Only Finland and the United States have implemented Article 17, allowing court appointed commissioners to take depositions upon request from any State Party. The United Kingdom allows such depositions on a reciprocal basis. Some countries, like Denmark and Portugal, have prohibited any such depositions.
} 
In most United States courts, a party requesting that the Hague Convention procedures be used instead of the FRPC bears the burden of persuasion. ${ }^{64}$ In Societe Nationale Industrielle Aerospatiale, et al. v. United States District Court for the Southern District of Iowa (“Aerospatiale”), the Supreme Court considered the extent to which parties must comply with the Hague Convention procedures when seeking discovery from a foreign litigant. ${ }^{65}$ The Court held that the Hague Convention is not the exclusive means of conducting discovery between State Parties, but acknowledged that the Hague Convention is "one method of seeking evidence that a court may elect to employ."66 The Court also noted that the Hague Convention may not be sufficient to provide guidance in certain circumstances as it does not adequately distinguish between third parties and parties to the litigation, or between evidence that is in the control of a party versus evidence abroad. ${ }^{67}$

However, the Supreme Court did not set a bright line rule in Aerospatiale. Instead, the Court provided a three-part test to guide the lower courts. Courts

\footnotetext{
${ }^{64}$ In re Vitamins Antitrust Litig., 120 F. Supp. 2d 45, 52 (D.D.C. 2000); Valois of America, Inc., 183 F.R.D. at 346; In re: Perrier Bottled Water Litig., 138 F.R.D. 348, 348 (D. Conn. 1991); Doster v. Schenk A.G., 141 F.R.D. 50, 51-52 (M.D.N.C. 1991); Rich v. KIS Ca., Inc., 121 F.R.D. 254, 260 (M.D.N.C. 1988); Benton Graphics v. Uddeholm Corp., 118 F.R.D. 386, 389 (D.N.J. 1987); but see Hudson v. Hermann Pfauter Gmb H \& Co., 117 F.R.D. 33, 33 (N.D.N.Y. 1987) (ruling that the burden of proof is on the party opposing the use of the Hague Convention); Knight v. Ford Motor Co., 615 A.2d 297, 300 (L. Div. 1992) (placing burden on the party opposing the Hague Convention).

${ }^{65} 482$ U.S. 522 (1987).

${ }^{66} I d$. at 534-41 (finding that the Hague Convention was drafted in permissive language rather than mandatory terms and arguing that to find the Hague Convention as the exclusive means for discovery among State Parties would provide foreign litigants an unfair advantage in United States courts).

${ }^{67}$ Id. at 541.
} 
should consider: "[1] the particular facts, [2] sovereign interests, and [3] likelihood that resort to [the Hague Convention's] procedures will prove effective.”68 The Supreme Court cautioned the trial courts to "exercise special vigilance to protect foreign litigants from . . . unnecessary [] or unduly burdensome discovery . . .."69

Following Aerospatiale, courts have justified resorting to the FRCP over the Hague Convention, citing time pressure on the litigation ${ }^{70}$, ineffectiveness of Hague Convention procedures ${ }^{71}$, and the inability to separately describe each document $_{\text {sought. }}{ }^{2}$ Other courts have found that employing the Hague Convention is more appropriate when complying with the FRCP would subject a party to criminal sanctions in their home country ${ }^{73}$, or when "inconveniences occasioned by the ... Hague Convention procedures 'pale besides the importance of respecting [the foreign] sovereign interests.",74 The Aerospatiale balancing test has been consistently applied to merits discovery ${ }^{75}$ and non-party

\footnotetext{
${ }^{68} I d$. at 544 .

${ }^{69}$ Id. at 546 .

${ }^{70}$ Bodner, 202 F.R.D. at 376.

${ }^{71}$ In re: Vitamins Antitrust Litig., 2001 LEXIS 8904, at *32.

${ }^{72}$ First Am. Corp. v. Price Waterhouse LLP, 154 F.3d 16, 23 (2d Cir. 1998).

${ }^{73}$ Motorola Credit Corp. v. Uzan, 2003 WL 203011, at*7 (S.D.N.Y. Jan. 29, 2003) (finding that defendant and its employees may be subject to criminal sanctions in Switzerland if they responded to plaintiffs' subpoena issued pursuant to the FRCP without authorization from a Swiss court).

${ }^{74}$ In re Perrier Bottled Water Litig., 138 F.R.D. at 355 (internal citation omitted).

${ }^{75}$ See, e.g., Aerospatiale, 482 U.S. 522; First Am. Corp., 154 F.3d 16.
} 
subpoenas. ${ }^{76}$ The question still remains as to whether the balancing test should be applied to jurisdictional discovery, or whether the Hague Convention is required. $^{77}$

In a 2003 review of the Hague Convention initiated by a Special Commission convened by the Hague Conference on Private International Law, United States litigators cited concerns about the amount of time discovery would take under the Hague Convention as the main reason for seeking discovery under the FRCP. ${ }^{78}$ In addition, the litigators surveyed expressed concerns regarding the assertion of foreign evidentiary privileges and the inability to identify the documents sought with the specificity required by the foreign country. ${ }^{79}$

\footnotetext{
${ }^{76}$ See, e.g., Minpeco, 116 F.R.D. at 526-27 (noting that it is "important to focus on the status in the litigation at hand of the party resisting discovery.”); Gap, Inc. v. Stone Int’l Trading, Inc., 1994 WL 38651, at *1 (S.D.N.Y. Feb. 4, 1994). In determining what rule to apply, "courts commonly look to the status of the person from whom discovery is sought as one factor in determining whether to apply the provisions of the [Hague Convention]”. Id.

${ }^{77}$ Many jurisdictions have found that there is no reason not to apply Aerospatiale to disputes involving personal jurisdiction. In re Vitamins Antitrust Litig., 120 F.Supp.2d 45, 50 (D.D.C. 2000) (finding that the Aerospatiale balancing test should be applied to jurisdictional discovery); see also, Rich, 121 F.R.D. at 260 (noting that Aerospatiale "did not carve out any exception for disputes involving personal jurisdiction”); In re Bedford Computer Corp., 114 B.R. 2, 5-6 (Bankr. D.N.H. 1990) (citing to Rich and holding that jurisdictional discovery proceed under the FRCP). However, some courts have found that jurisdictional discovery must proceed under the Hague Convention "to protect[] a foreign litigant in light of the jurisdictional problems. Jenco v. Martech Int’l, Inc., 1988 WL 54733, at *1 (E.D.La. May 19, 1988); see also, Knight, 615 A.2d at 301 n. 11 (noting in dicta that "[i]f jurisdiction does not exist over a foreign party ..., the Convention may provide the only recourse for obtaining evidence.”).

${ }^{78}$ Office of Legal Adviser for Private International Law, United States Department of State, Report on Survey of Experience of U.S. Lawyers With the Hague Evidence Convention Letter of Request Procedures 11 (2003).

${ }^{79} I d$.
} 


\section{FRCP or Other Law}

For those countries that are not signatories to the Hague Convention, letters rogatory can be used to request aid from a foreign court to secure documents and data in discovery. ${ }^{80}$ The Aerospatiale balancing test has not been applied to cases where there is a conflict between the FRCP and laws of countries that are not signatories to the Hague Convention. ${ }^{81}$ However, the Supreme Court in Aerospatiale did outline in dicta the factors to consider in any comity analysis:

(1) the importance to the . . litigation of the documents or other information requested;

(2) the degree of specificity of the request;

(3) whether the information originated in the United States;

(4) the availability of alternative means of securing the information; and

(5) the extent to which noncompliance with the request would undermine important interests of the United States, or compliance with the request would undermine important interests of the state where the information is located. ${ }^{82}$

Further, in In re Vitamins Antitrust Litigation, the District Court in the

District of Columbia applied a two-part test to determine whether to apply the FRCP or the law of the country where discovery was sought. ${ }^{83}$ First, the court

\footnotetext{
${ }^{80}$ This procedure is recognized by the Federal courts. 28 U.S.C.A. § 1781; Fed. R. Civ. P. 28(b).

${ }^{81}$ See In re Vitamins Antitrust Litig., 120 F. Supp. 2d 45, 50 (D.D.C. 2000) (holding that "[s]ince Japan and Belgium chose not to adopt the [Hague Convention], any analysis of the Aerospatiale factors would seem wholly irrelevant to these nations.”); McKesson Corp. v. Islamic Rep. of Iran, 185 F.R.D. 70, 79 (D.D.C. 1999) (holding that Aerospatiale is of limited assistance since Iran is not a party to the Hague Convention); Japan Halon Co., Ltd. v. Great Lakes Chem. Corp., 155 F.R.D. 626, 627 (N.D.Ind. 1993) ("because Japan is not a signatory to the Hague Convention on Evidence, any analysis of case law on that point is rendered moot”).

82482 U.S. at 544 n.28 (quoting the then tentative draft of the Restatement of Foreign Relations Law).

${ }^{83} 120$ F. Supp. 2d at 55.
} 
considered whether there was a conflict between the FRCP and foreign law. ${ }^{84}$ Second, when the court found there was a conflict, the court analyzed principles of comity to determine whether use of foreign law was appropriate. ${ }^{85}$ In that case, the court reviewed Japanese and Belgian discovery laws.

The court found that Japanese law was extremely adverse to United States discovery and that, if used, it would not be likely to obtain the necessary discovery. ${ }^{86}$ Finding that discovery should proceed under the FRCP, the court noted that “despite the Court's respect for the principles of comity and Japan's sovereign interests in protecting its citizens from unduly burdensome discovery, this Court cannot find that these concerns outweigh the need for prompt and efficient resolution of the jurisdictional questions in this case.”87

The court's analysis of the Belgian law was similar. Finding that the Belgium law "generally disfavors pretrial discovery in civil litigation,” the court held that discovery could not be realized under Belgium law because of the strict specificity requirements, and so discovery should proceed under the FRCP. ${ }^{88}$

\footnotetext{
${ }^{84}$ Id. at 55-57.

${ }^{85} \mathrm{Id}$.

${ }^{86} I d$. at 56.

${ }^{87} I d$.

${ }^{88}$ Id. at $56-57$.
} 


\section{Orders of Production}

\section{Subpoena Power and Personal Jurisdiction}

Discovery may be obtained on "any matter, not privileged, that is related to the claim or defense of any party.” ${ }^{89}$ Under the FRCP and like state rules, a party in litigation may serve on any party, or in some cases a non-party, a request for documents, including ESI, in that party’s "possession, custody or control." 90 Generally, if a party or non-party refuses to comply with a discovery request, a court may order any entity subject to its jurisdiction to disclose the information whether or not local foreign law prohibits disclosure. ${ }^{91}$ In order to exercise this power, the court must have both personal jurisdiction over the entity and the entity must have control over the documents requested. ${ }^{92}$ Personal jurisdiction over foreign litigants in federal courts is analyzed using the familiar minimum contacts test announced in International Shoe Co. v. Washington. ${ }^{93}$ The location of the documents is irrelevant. ${ }^{94}$

\footnotetext{
${ }^{89}$ FED. R. CIV. P. 26(b)(1).

${ }^{90}$ FED. R. CIV. P. 34(a).
}

${ }^{91}$ E.g., Aerospatiale, 482 US. 522.; see also RESTATEMENT (ThiRD) OF ForEIGN RELATIONS LAW $\S 442(1)(a)$ (stating that "[a] court or agency in the United States ... may order a person subject to its jurisdiction to produced documents, objects, or other information relevant to an action or investigation, even if the information of the person in possession of the information is outside the United States.”).

${ }^{92}$ U.S. v. First Nat'l City Bank, 396 F.2d 897, 900-01 (2d Cir. 1968); In re Grand Jury Supoenas Duces Tecum Addressed to Canadian Int'l Paper Co., 72 F. Supp. at 1020 (reasoning that a United States subsidiary of a Canadian parent company had control over the withheld documents located at the parent company simply because the parent had possession and the subpoena had been served on some of its officers).

93326 U.S. 310 (1945). Under International Shoe, United States courts may exercise personal jurisdiction over foreign parties and non-parties if they have minimum contacts with the forum and if exercising jurisdiction is fair and just. Id. at 316. Courts have found personal jurisdiction over an organization that "purposefully avails itself of the privilege of conducting activities within the forum,” Hanson v. Denckla, 357 U.S. 235, 253 (1958). Under this analysis, foreign companies 


\section{2. "Control" of Data}

In discovery, a party may request documents in the "responding party's possession, custody, or control.”95 As long as the responding party has a legal right to the requested information, it is deemed to have custody and control regardless of whether the information is beyond jurisdiction of the court. ${ }^{96}$ "Even records kept beyond the territorial reach of the district court issuing the subpoena may be covered if they are controlled by someone subject to the court's jurisdiction. ${ }^{97}$ The issue of control becomes less clear when dealing with parents and subsidiaries or affiliates located abroad.

In In re Uranium Antitrust Litigation, the District Court in the Northern District of Illinois analyzed the issue of defendants' control of documents of corporate affiliates located outside of the United States. ${ }^{98}$ The court employed a balancing test to determine whether the United States companies had control over the foreign documents. A number of factors were considered including: (1) the parent's ownership share in the subsidiary or affiliate; (2) whether the parent and the subsidiary or affiliate had interlocking management structures; and (3) the

that have purposefully availed themselves of the privilege of conducting business in the United States are subject to the personal jurisdiction of the courts in the forum they conduct business.

${ }^{94}$ In re Grand Jury Supoenas Duces Tecum Addressed to Canadian Int'l Paper Co., 72 F. Supp. at 1020.

${ }^{95}$ FED. R. CIV. P. 34(a)(1).

${ }^{96}$ Buckley v. Vidal, 50 F.R.D. 271, 274 (S.D.N.Y. 1970); see also Mercy Catholic Med. Ctr. V. Thompson, 380 F.3d 142, 160 (3d Cir. 2004).

${ }^{97}$ 9A Federal Practice ANd Procedure § 2456, at 31 (2d ed. 1995 \& 2004 Supp.).

${ }^{98} 480$ F. Supp. at 1144. 
degree of controlled exercised by the parent over the subsidiary or affiliate's management and employees. ${ }^{99}$

In applying this balancing test, courts have often required the production of international data. In In re Uranium Antitrust Litigation, the court analyzed the four defendants separately. ${ }^{100}$ In the instances where the court found that the corporate defendant had control over the foreign documents, the court was persuaded by the fact that the foreign subsidiaries were wholly owned, and that the parent and the foreign subsidiary had interlocking management structures. ${ }^{101}$ In another instance, however, the court found that the foreign subsidiary had "its own books and records and [held] its own corporate meetings separate and apart from any other company,” and so the United States parent did not have control over the documents. ${ }^{102}$

In Afros S.P.A. v. Krauss-Maffei Corp., the District Court in the District of Delaware ordered production of documents by a foreign, non-party parent company because the defendant not only operated as exclusive seller of the nonparty's products in the United States, but also demonstrated its ability to reach the requested documents through the presence of several of the non-party parent's employees on the defendant's board of directors. ${ }^{103}$

\footnotetext{
${ }^{99}$ Id. at 1148.

${ }^{100} I d$. at $1151-53$.

${ }^{101} I d$. at $1152-53$.

${ }^{102}$ Id. at 1152.

103 113 F.R.D. 127, 131-32 (D. Del. 1986).
} 


\section{Conflicts with Foreign Law and the Balancing Test}

Once a court has established that it has personal jurisdiction to order discovery and that the foreign entity from which discovery is sought has control of the requested data, it still must determine whether ordering discovery is appropriate in view of foreign laws prohibiting disclosure. A foreign party seeking protection from discovery claiming that foreign law bars compliance with the request bears the burden of showing that the discovery request is actually in conflict with foreign law. ${ }^{104}$ To satisfy that burden, "the party resisting discovery must provide the Court with information of sufficient particularity and specificity to allow the Court to determine whether the discovery sought is indeed prohibited by foreign law.”105

In Societe Internationale, the plaintiff, a Swiss holding corporation, sought to recover assets seized by the United States under the Trading with the Enemy Act. ${ }^{106}$ The government demanded that the plaintiff produce Swiss banking records. The plaintiff refused, claiming that the production would violate Article 273 of the Swiss Penal Code ${ }^{107}$ and Article 47 of the Swiss Bank Law. ${ }^{108}$ The Supreme Court first held that defendants did have control of the documents despite the Swiss law prohibiting disclosure; it further noted that to hold

\footnotetext{
${ }^{104}$ See e.g., In Re Sealed Case, 825 F.2d at 498; Vetco, 691 F.2d at 1289.

${ }^{105}$ Alfadda v. Fenn, 149 F.R.D. 28, 34 (S.D.N.Y. 1993).

106357 U.S. 197, 198-99 (1958).

${ }^{107}$ Prohibiting economic espionage.

${ }^{108}$ Prohibiting disclosure of banking records.
} 
otherwise would "invite efforts to place ownership of American assets in persons or firms whose sovereign assures secrecy of records." ${ }^{109}$

The Supreme Court then considered whether the district court properly compelled disclosure despite the fact that plaintiffs would be unable to comply under Swiss law. In holding that the motion to compel was appropriate, the Supreme Court considered: (1) the United States interest in identifying enemies disguising their financial interests; (2) the "vital influence" the documents could have on the litigation; and (3) the fact that defendants were in the best position to seek relaxation of penal laws in order to comply with the order. ${ }^{110}$ The Supreme Court ultimately called for a balancing approach and cautioned that each case must be evaluated on its own merits. ${ }^{111}$

Because Societe Internationale did not specifically outline the factors that should be balanced in each case, courts have looked at a variety of factors. Some courts have considered the factors outlined in the Restatement's comity analysis, ${ }^{112}$ including: (1) the importance to the litigation of the information sought; ${ }^{113}$ (2) the degree of specificity of the request; ${ }^{114}$ (3) whether data

\footnotetext{
${ }^{109} 357$ U.S. at 205.

110357 U.S. at 205-06.

111357 U.S. 197, 205-06.

${ }^{112}$ Restatement (Third) of the Foreign Relations Law $§ 442$.

${ }^{113}$ Societe Internationale, 357 U.S. at 205 (finding that the documents sought exerted a "vital influence" over the litigation); Strauss v. Credit Lyonnais, S.A., 242 F.R.D. 199, 212 (E.D.N.Y. 2007) (calling the requested information "highly relevant"); Minpeco, 116 F.R.D. at 527-28 (noting that discovery would be unlikely to produce significant information for the litigation); In re Uranium Antitrust Litig., 480 F. Supp. at 1155 (finding that the heart of any American antitrust case is the discovery of business documents) (citations omitted).
} 
requested originated in the United States; ${ }^{115}$ (4) whether the same information could be obtained from other means; ${ }^{116}$ and, perhaps most importantly, (5) the competing interests of the nations whose laws are in conflict. ${ }^{117}$ Additionally, some other factors courts have balanced include: (1) the hardship of compliance on the party resisting the discovery request; ${ }^{118}$ (2) the good faith of the party from

${ }^{114}$ Strauss, 242 F.R.D. at 212 (describing the discovery request as "narrowly tailored"); British Int'l Ins. Co. v. Seguros La Republica, S.A., 2000 U.S. Dist. LEXIS 7509, at *28 (S.D.N.Y. June 1,2000 ) (noting that defendants failed to make any objections to the requests being overbroad).

${ }^{115}$ British Int'l Ins. Co. Ltd., 2000 U.S. Dist. LEXIS 7509, at *28-29 (acknowledging that all information sought was located in Mexico); see also Strauss, 242 F.R.D. at 209 (clarifying that the Restatement meant to consider "whether the 'information originated in the United States,' not whether the information currently is located in the United States") (citations and quotes omitted).

${ }^{116}$ Strauss, 242 F.R.D. at 212 (noting that discovery could be obtained through Hague Convention avoiding sanctions under foreign law); British Int'l Ins. Co. Ltd., 2000 U.S. Dist. LEXIS 7509, at *29 (pointing out that there was no other means of obtaining the requested information).

${ }^{117}$ Generally, courts have found the United States' interests to supersede foreign interest. First Am. Corp., 154 F.3d at 21-22 (holding that American interests in discovery outweighed British interests in confidentiality); Bodner, 202 F.R.D. at 375 (finding that the United States' interest in assuring restitution to Holocaust victims was strong and that there was no competing French interest); First Nat'l City Bank, 396 F.2d at 903 (finding Germany’s interests in bank secrecy to be limited because the country chose to "leave the matter of enforcement to the vagaries of private litigation"). Courts have compelled discovery when there appeared to be a mutual interests between the United States and the foreign country. Strauss, 242 F.R.D. at 213 (acknowledging the French and United States mutual interest in thwarting terrorism). Occasionally, courts have found that foreign interests are substantial. Minpeco, 116 F.R.D. at 527-28 (finding that Switzerland had a substantial interest in protection of bank client account information). Criminal discovery orders “appear to serve a more pressing national function than civil discovery." Vetco, 691 F.2d at 1288. Where a foreign government has articulated a specific government interest, courts have found it persuasive as to a significant foreign interest, but not dispositive. Societe Internationale, 357 U.S. at 200-01 (declining to order production of documents where the Swiss government confiscated records to prevent discovery); cf. Strauss, 242 F.R.D. at 219 (noting the "absence of any articulated interest by the French government”).

118 The hardship analysis has often rested on whether the party from whom discovery is sought is at risk of prosecution under a criminal statute. See, e.g., Minpeco, 116 F.R.D. at 527-28 (finding there was a significant risk of prosecution under the foreign criminal statute); Aerospatiale, 482 US. at 526 (no significant risk of prosecution); First Nat'l City Bank, 396 F.2d at 899-900 (finding no risk of criminal sanctions and a "remote and speculative" risk of civil liability). Courts have also taken into account the scope of the discovery request and whether a protective order can reduce the hardship on the party producing the information. See, e.g., Bodner, 202 F.R.D. at 376 (noting that protective order addressed confidentiality concerns). 
whom discovery was sought; ${ }^{119}$ and (3) whether the request was being made of a party or non-party. ${ }^{120}$

Almost every case weighs the competing interests of the foreign state against the interests of the United States. Often, courts find that United States interests in discovery outweigh any foreign state interest. ${ }^{121}$ The scale tends to tip in favor of United States' interests based on the perspective held by many United States courts and expressed by Judge Learned Hand that, "[t]he suppression of truth is a grievous necessity at best, more especially where as here the inquiry concerns the public interest; it can be justified at all only where the opposing private interest is supreme." ${ }^{122}$ In certain circumstances, though, a foreign state’s interest in protecting certain information has prevailed. ${ }^{123}$

\footnotetext{
${ }^{119}$ Quaak v. KPMG, 361 F. 3d 11, 21 (1st Cir. 2004) (court faulted KPMG for not seeking clarification on the law from the Belgian courts before refusing to turn over the information); First Nat'l City Bank, 396 F.2d at 900 (noting the bank had not acted in good faith because it did not inquire as to whether the bank secrecy privilege applied to the records in question, and did not produce records that were clearly not covered by the privilege); Minpeco, 116 F.R.D. at 528 (commending the bank's "extensive attempts to secure waivers" from the bank secrecy laws and barring discovery).

${ }^{120}$ Courts are more reluctant to order production of information located abroad when the foreign entity is not a party to the litigation. In Ings $v$. Ferguson, the court held that an order to produce Canadian banking documents served on the New York branches of two foreign banks should be modified to require production only of the New York documents. 282 F.2d 149, 153 (2d. Cir. 1960). In deciding that the order was overbroad the court noted that "[s]ubpoena power is not absolute," and that "[n]o claim is being made against either bank by any litigant." Id. The court further commented that the transactions in question did not originate in the New York branches of these banks. Id. at 152 .

${ }^{121}$ See, e.g., Bodner, 202 F.R.D. at 375 (finding that the United States interest in assuring restitution to Holocaust victims was strong and that there was no competing French interest); First Am. Corp., 154 F.3d at 21-22 (holding that American interests in discovery outweighed British interests in confidentiality).

${ }^{122}$ McMann v. S.E.C., 87 F.2d 377, 378 (2d Cir. 1937), cert. denied; McMann v. Engle, 301 U.S. 684 (1937).

${ }^{123}$ Minpeco, 116 F.R.D. at 527-28 (finding that Switzerland had a substantial interest in protection of bank client account information).
} 


\section{Additional Considerations for International Discovery of ESI}

\section{A. Balancing for International ESI}

Courts have surprisingly avoided significant international e-discovery issues to date, leaving little case law to guide the inevitable cases to come. Neither the Restatement nor the FRCP alone provides sufficient guidance on how to handle discovery of international ESI. The Restatement outlines a useful comity analysis ${ }^{124}$ but fails to consider the unique aspects of ESI, including the additional hardships of collecting, reviewing, and producing ESI. The FRCP fills in some of the gaps by providing some factors to consider for discovery of ESI, but does not provide guidance on how to balance those factors with international comity concerns.

Since the December 1, 2006 amendments to the FRCP, courts have applied the seven-factor test outlined in the Advisory Committee Note to Rule 26 to determine whether to compel discovery. ${ }^{125}$ The balancing test includes many of the same factors outlined by the Restatement's comity analysis for international discovery, ${ }^{126}$ including: (1) the specificity of the discovery request; (2) the quantity of information available from other and more easily accessed sources; and (3) the importance of the issues at stake in the litigation. It also includes other factors specifically meant to address the unique issues of e-discovery, including: (1) the failure to produce relevant information that seems likely to

\footnotetext{
${ }^{124}$ See supra notes 112-117, and accompanying text.

${ }^{125}$ See, e.g., Disability Rights Council of Greater Wash. v. Wash. Metro. Transit Auth., 242 F.R.D. 139, 147-48 (D.D.C. 2007).

${ }^{126}$ See supra notes $112-117$, and accompanying text.
} 
have existed but is no longer available on more easily accessed sources; (2) the likelihood of finding relevant, responsive information that cannot be obtained from other, more easily accessed sources; (3) predictions as to the importance and usefulness of the further information; and (4) the parties’ resources. ${ }^{127}$

The seven-factor test is meant to take into account the hardships inherent in discovery of ESI. However, the test alone is not sufficient to address discovery of international ESI because it does not address issues of comity that have historically been considered by courts in deciding on international discovery issues. ${ }^{128}$ The seven-factor test - in combination with a comity analysis - will be needed to adequately address the unique issues presented by discovery of international ESI. Although the blended approach implicates the consideration of a number of factors, some are particularly impacted by the unique circumstances presented by international ESI.

\section{Hardship of Compliance}

In addition to the traditional hardship considerations that have been considered by courts in international discovery, such as whether a party is subject to criminal penalties or whether the hardship can be mitigated by narrowing the

\footnotetext{
${ }^{127}$ Disability Rights Council of Greater Wash., 242 F.R.D. at 147-48.
}

\footnotetext{
${ }^{128}$ These include the factors outlined by the Restatement, including: (1) the importance to the litigation of the information sought, (2) the degree of specificity of the request; (3) whether data requested originated in the United States; (4) whether the same information could be obtained from other means; and, perhaps most importantly, (5) the competing interests of the nations whose laws are in conflict. See supra notes 112-17. It also includes factors outlined by courts outside of the Restatement's comity analysis including: (1) the hardship of compliance on the party resisting the discovery request; (2) the good faith of the party from whom discovery was sought; and (3) whether the request was being made of a party or non-party. See supra notes 118-20.
} 
discovery request or issuing a protective order, ${ }^{129}$ discovery of international ESI will involve additional hardship considerations. Due to the sheer volume of ESI, the same considerations that courts must consider domestically in determining whether a discovery request is reasonable must be considered with international ESI, including the accessibility of the data and the cost to collect, review, and produce enormous volumes of ESI. ${ }^{130}$

Revised FRCP Rule 26(b)(2) states that a party "need not provide discovery" of ESI from sources that the party identifies as "not reasonably accessible because of undue burden or cost." ${ }^{\text {"131 }}$ Courts have considered the format of the ESI and whether it is reasonably accessible in determining whether compliance with discovery would be unduly burdensome. In Zubulake v. UBS Warburg LLC, the District Court in the Southern District of New York identified inaccessible data formats as data on certain backup tapes and "erased, fragmented or damaged" data; it also defined data that is "not readily usable" as inaccessible. ${ }^{132}$ Certainly these same accessibility definitions and applications to whether compliance is unduly burdensome will apply to international data.

\footnotetext{
${ }^{129}$ See supra note 118.

${ }^{130}$ The use of computers, e-mail, and other sources of electronically stored information ("ESI”) have resulted in an exponential increase in the amount of ESI companies store. Corinne L. Giacobbe, Allocating Discovery Costs in the Computer Age: Deciding Who Should Bear the Costs of Discovery of Electronically Stored Data, 57 WASH. \& LEE L. REV. 257, 262 (2000). Companies can store a vast amount of data online and even more on backup tapes. One 8millimeter magnetic backup tape can store the equivalent of 1500 boxes of paper. Id. at 263. See also supra note 13.

${ }^{131}$ FED. R. CIV. P. 26(b)(2)(B).

132217 F.R.D. 309, 319-20 (S.D.N.Y. 2003); see also W.E. Aubuchon Co. v. BeneFirst, LLC, 245 F.R.D. 38, 42. (D. Mass. Feb. 6, 2007) (applying Zubulake to amended Rule 26(b)(2)).
} 
In addition to data in inaccessible formats, courts will have to consider the cost to collect, review, and produce the ESI requested. Experience from domestic litigation shows that even the most routine litigation can result in an enormous amount of ESI - exponentially increasing the costs of discovery. For example, in a whistleblower action in Wisconsin, the plaintiff's request for all "documents, notes, memos, e-mails and metadata of any [official] regarding the reorganization or restructuring of the [agency]" resulted in two hard drives containing four terabytes $^{133}$ of ESI. ${ }^{134}$ In a recent California prison mental health care class action suit, defendants indicated that they collected over three terabytes of data from over eighty custodians and another forty gigabytes of data from exchange servers from four state agencies. ${ }^{135}$

Although United States courts have balanced the cost to collect, review, and produce data since the December 1, 2006 revisions to the FRCP, costs alone have rarely swayed them to dismiss a motion to compel production or to shift costs. ${ }^{136}$ However, when combined with other factors related to the difficulties in producing international data, discovery costs may have a greater impact on courts'

\footnotetext{
${ }^{133}$ A terabyte is 1024 gigabytes or the equivalent to 500 billion typewritten pages. Haka v. Lincoln County, 246 F.R.D. 577, 578 n.1 (W.D. Wis. 2007).

${ }^{134}$ Id. at 578.

${ }^{135}$ Coleman v. Schwarzenegger, 2007 WL 4328476, No. CIV S-90-0520, slip op. at 1 (E.D.Ca. Dec. 6, 2007). Defendants further noted that if the data were printed out it would comprise "approximately 45,000 boxes of copy paper, which if stacked on top of each other would be approximately 37,500 feet or 7.1 miles tall.” Id.

${ }^{136}$ PSEG Power N.Y., Inc. v. Alberici Const., Inc., 2007 U.S. Dist. LEXIS 66767, at *34-35 (N.D.N.Y. Sept. 7, 2007 ) (placing burden of cost on responding party because they were in the position to control costs); Parkdale Am. v. Travelers Cas. \& Sur. Co. of Am., 2007 U.S. Dist. LEXIS 88820, at *34-36 (W.D.N.C. Nov. 19, 2007) (overruling objections to discovery defendant's claimed was too costly).
} 
decisions of whether to compel production. In addition, courts should consider the costs to translate international ESI into English for both review and production. At least one court has found the mere need to translate to be unpersuasive in showing undue burden. ${ }^{137}$

\section{Good Faith of Party Opposing the Discovery}

In addition to hardship considerations, courts should consider the good faith of the party opposing discovery. Both good faith in placing ESI abroad and good faith in trying to produce ESI where production is prohibited by foreign law should be considered. In Societe Internationale, the Supreme Court recognized that willful concealment of information in foreign states for the purposes of avoiding discovery would "have vital bearing” on whether to dismiss an action. ${ }^{138}$ Presumably the Court would also find willful concealment an important factor to consider in whether to order production. With the growth of international data infrastructures and global companies, courts should explore a party's motivations for placing data in countries with laws that prohibit production of ESI in United States courts.

While privacy laws, blocking statutes, and other international laws protecting the transfer of information to the United States for discovery in litigation can sometimes be an insurmountable obstacle, some international laws

\footnotetext{
${ }^{137}$ In re Application of Gemeinshcaftspraxis Dr. Med. Schottdorf, 2006 WL 3844464, No. Civ. M19-88, slip op. at 8 (S.D.N.Y. Dec. 29, 2006).

${ }^{138} 357$ U.S. at 208-09 (noting that there were not enough facts to support the Government's contention that the assets of a German company had been transferred to a Swiss holding company in order to take advantage of Swiss secrecy laws).
} 
provide for exceptions. Whether the international entity subject to a discovery request seeks an exception to these foreign laws should be considered by courts in making their orders to produce. ${ }^{139}$ In many international discovery cases, courts have only considered good faith as a factor in deciding sanctions, not in determining whether to compel production. ${ }^{140}$ At least one court, however, has listed good faith as a factor in deciding an order to compel. ${ }^{141}$ As international discovery of ESI becomes more prevalent, good faith efforts to secure exceptions to foreign law will become a more important factor in deciding orders to compel.

\section{Requests to Parties and Non-Parties}

The enormous volume of ESI and the associated costs to collect, review, produce, and sometimes translate create an even greater burden on any international entity required to comply with a discovery request. In particular, these costs may be too burdensome for non-parties. In United States $v$. Amerigroup Illinois, Inc., the District Court in the Northern District of Illinois noted the "unique burden" associated with a non-party having to restore backup tapes to obtain e-mail for discovery when it quashed the subpoena under Rule $45(\mathrm{c}){ }^{142}$

\footnotetext{
${ }^{139}$ See supra note 119.

${ }^{140}$ Richmark, 959 F.2d at 1479 (ordering contempt sanctions); First Nat'l City Bank, 396 F.2d at 900 (ordering contempt sanctions).

${ }^{141}$ Minpeco, 116 F.R.D. at 528 (listing good faith as a factor to consider in deciding an order to compel).

1422005 WL 3111972, at *7 (N.D. Ill. Oct. 21, 2005).
} 
Courts should consider shifting costs to the requesting party when the discovery request is made of a nonparty. ${ }^{143}$ FRCP 45 (c) provides that "an order to compel production shall protect any person who is not a party . . . from significant expense resulting from the inspection and copying commanded.”144 This is because "nonparty witnesses are powerless to control the scope of litigation and discovery, and should not be forced to subsidize an unreasonable share of the costs of a litigation to which they are not a party." ${ }^{445}$ In In re Automotive Refinishing Paint Antitrust Litigation, the government made significant requests to a nonparty foreign trade association. ${ }^{146}$ The District Court in the Eastern District of Pennsylvania limited the scope of the discovery request and shifted the cost of discovery to the requesting party. ${ }^{147}$ Whether limiting discovery, shifting the cost of discovery, or prohibiting discovery altogether, courts will need to pay special attention to third-parties especially in the international context.

\footnotetext{
${ }^{143}$ See First Am. Corp. v. Price Waterhouse LLP, 184 F.R.D. 234, 241 (S.D.N.Y. 1998) ("[a] nonparty's legal fees, especially where the work benefits the requesting party, have been considered a cost of compliance reimbursable.").

${ }^{144}$ FED. R. CIV. P. 45(c)(2)(B).

${ }^{145}$ U.S. v. Columbia Broad. Sys., 666 F.2d 364, 371 (9th Cir. 1982).

146229 F.R.D. 482, 485 (E.D.Pa. 2005).

147229 F.R.D. 482, 496 (E.D.Pa. 2005).
} 


\section{Whether ESI Originated in the United States}

Although listed as a factor in the Restatement, the origin of the data has not been weighed in many international discovery cases. ${ }^{148}$ However, the origin of ESI will become an increasingly important issue as companies look to cheaper data storage abroad.

The transient nature of electronic data and the fact that electronic data can be created in one country, hosted in another, and used in an entirely separate country may create a question of whether the laws of any one of these countries affects whether the data can be produced in United States litigation. The origin of the ESI will be key to answering this question. Whether data was created in the country in which it is hosted will also likely weigh into the balancing of interests. There is already some indication that data shared by entities in the United States and another country may be viewed as a joint interest. ${ }^{149}$ Additionally, international e-commerce law may help courts discern foreign interests in some of the more transient types of ESI. ${ }^{150}$

\footnotetext{
${ }^{148}$ The issue was discussed briefly in both British Int'l Ins. Co. Ltd., 2000 U.S. Dist. LEXIS 7509, at *28-29, and Strauss, 242 F.R.D. at 209, but was not a significant factor in either case.

${ }^{149}$ Vetco, 691 F.2d at 1281 (finding Swiss business secrets statute did not reflect a "totally Swiss" interest when dealing with a Swiss subsidiary of a United States parent) (internal citations omitted).

${ }^{150}$ The E-Commerce Directive, enacted by the European Union for its member States, directs that member states should supervise internet services where they "originate" - implying a focus on origin. Council Directive 2000/31/EC, 2000 O.J. (L 178) (EC).
} 


\section{B. Recourse for Non-Production}

Rule 37(b)(2) of the FRCP lists a variety of sanctions that a court may order if a party refuses to comply with discovery. Sanctions under Rule 37(b)(2) must be "just" and must relate to the particular claim at issue. ${ }^{151}$ In Societe Internationale, the Supreme Court held that Rule 37 may be invoked even if foreign law prohibits disclosure of the information sought. ${ }^{152}$ However, Rule 37 permits a party that is unable to comply with a discovery request to present "substantial justification" for its failure to disclose and avoid contempt sanctions. ${ }^{153}$ The rule has a specific safe harbor provision addressing the failure to provide ESI, which states that "[a]bsent exceptional circumstances, a court may not impose sanctions under these rules on a party for failing to provide electronically stored information lost as a result of the routine, good-faith operation of an electronic information system.” There is no specific provision, however, addressing the failure to provide ESI due to purported international legal restrictions.

Courts have historically considered "case killer" sanctions, including motions to dismiss and adverse inference instructions for failure to provide international data for discovery. Both are discussed below.

\footnotetext{
${ }^{151}$ Insurance Corp. of Ir., Ltd. v. Compagnie Des Bauxites de Guinee, 456 U.S. 694, 707 (1982).

152357 U.S. at 208.

${ }^{153}$ FED. R. CIV. P. 37(c)(1). See also Fonseca v. Regan, 734 F.2d 944, 948 (2d Cir. 1984), cert. denied, Rep. Columbia v. Fonseca, 469 U.S. 882 (1984) (“[W]here the information sought is not properly discoverable, it is axiomatic that a district court should not impose a Rule 37 sanction for a party's failure to comply with an order to reveal such information.”).
} 


\section{Motions to Dismiss}

Although severe, courts may consider dismissing a case based on a failure to comply with a discovery order, especially where the failure was due to a willful concealment of data in countries with laws prohibiting production in United States discovery. The United States Supreme Court has recognized that where a party has “deliberately courted legal impediments to production” by willfully concealing information in countries with strict data protection laws, dismissal may be warranted. ${ }^{154}$ However, a motion to dismiss based on failure to comply with a discovery order may violate Fifth Amendment protections providing that no person shall be deprived of property without due process of law. ${ }^{155}$ In Societe Internationale, the Supreme Court held that Rule 37 does not authorize a court to dismiss a complaint based on a failure to comply with discovery if that failure was “due to inability, and not to willfulness, bad faith, or any fault of [the party]." 156

Here again, a party's good faith will play a big role in what, if any, sanctions will apply. If a party willfully concealed information in a foreign location to avoid discovery or made no effort to procure an exception to the foreign law blocking production of the data, then a motion to dismiss may be warranted. With the growth of globalization, motives and actions with regard to a company's foreign business practices will be of increasing interest to courts.

\footnotetext{
${ }^{154}$ Societe Internationale, 357 U.S. at 208-09.

${ }^{155}$ Hovey v. Elliott, 167 U.S. 409 (1897); Hammond Packing Co. v. Ark., 212 U.S. 322 (1908).

${ }^{156} 357$ U.S. at 212.
} 


\section{Adverse Inference Instructions}

Short of dismissal, a court may allow adverse inferences to be drawn where a party fails to comply with an order for discovery of international ESI. The Supreme Court in Societe Internationale left open the possibility that adverse inferences may be drawn at trial due to the void in discovery. ${ }^{157}$ In light of Fifth Amendment concerns with dismissal, adverse inference instructions may be the fairest option - by providing the opportunity to litigate claims but not providing foreign litigants the unfair advantage of avoiding costly and burdensome e-discovery. Of course, as with any discovery decision made by courts, the same considerations that are balanced to determine whether to order production should be reviewed to determine what, if any, sanctions are appropriate.

\section{Conclusion}

Discovery of international ESI will inevitably be the next great discovery challenge United States courts will face. Existing law on international discovery and domestic e-discovery has provided a solid foundation for a balancing approach courts could use to evaluate discovery of international ESI. Discovery of international ESI necessitates special attention to the hardship of compliance, the good faith of the party opposing compliance, the status of the party of opposing compliance, and the origin of the ESI requested.

It will be interesting to see how discovery of international ESI plays out in United States courts. In performing a comity analysis, courts have historically

${ }^{157}$ Id. at 213. 
placed a high value on foreign interests. ${ }^{158}$ However, they have often allowed discovery notwithstanding the compelling foreign interest. ${ }^{159}$ When courts have to additionally balance the hardship considerations inherent with discovery of international ESI, the scales may tip in favor of denying discovery. However, bad faith in placing data in foreign locations and requests for data originating in the United States but stored in foreign locations may tip the scales toward compelling production. In addition, courts will increasingly encounter the question of what to do when a motion to compel is not complied with and may find that adverse inference instructions provide an avenue to encourage production that is fair and balanced.

\footnotetext{
${ }^{158}$ Minpeco, 116 F.R.D. at 527-28 (finding that Switzerland had a substantial interest in protection of bank client account information); Societe Internationale, 357 U.S. at 200-01 (declining to order production of documents where the Swiss government confiscated records to prevent discovery).

${ }^{159}$ First Am. Corp., 154 F.3d at 21-22 (holding that American interests in discovery outweighed British interests in confidentiality); Bodner, 202 F.R.D. at 375 (finding that the United States interest in assuring restitution to Holocaust victims was strong and that there was no competing French interest); First Nat'l City Bank, 396 F.2d at 903 (finding Germany's interests in bank secrecy to be limited because the country chose to "leave the matter of enforcement to the vagaries of private litigation”).
} 